\title{
What it Means When Your Work is Admired by Others: Observations of Employees of Professional Sport Organizations
}

\author{
Samuel Y. Todd \\ Georgia Southern University \\ Kenneth J. Harris \\ Indiana University Southeast
}

\begin{abstract}
Utilizing social identity theory (Tajfel \& Turner, 1986) as a guiding framework, this study investigated the way in which the evaluative dimension of group identification can ultimately affect employees' perceptions of work and their performance at work. From a matched sample of 103 employees and their managers working for professional sport clubs in the United States, we developed and tested a model that explains how elements of prestige and evaluative group identification (pride) ultimately lead to increased job performance. Our model explained $77 \%$ of the variance in job performance and $42 \%$ of the variance in job satisfaction. We offer several practical implications and future research ideas for extensions of this work.
\end{abstract}

\section{Introduction}

A great deal of management research has focused on the way work affects individuals. Scholars have noted that work affects employees in various ways including life satisfaction (Iverson \& Maguire, 2000), self esteem (Gardner \& Pierce, 1998), stress levels (Schaubroeck \& Merritt, 1997), job strain (Gemmill \& Heisler, 1972), work family conflict (Carlson \& Perrewé, 1999), and one's priorities in life (Paully et al., 1994). In the following sections, we suggest that work can affect the extent to which employees feel valued, admired, and especially respected by others. We take our arguments from social identity theory, which suggests people desire to be a part of positively evaluated groups or social categories because positive social identities contribute to enhanced feeling of general self worth (Tajfel \& Turner, 1986). Though this framework, many scholars from the social sciences to the organizational sciences have explored the effect that groups have on individuals. Virtually all of the work in this area has involved members' identification to the group, or some variation of it.

While most scholars who explore group identification do so from a unidimensional perspective, several scholars have suggested three components to group identification: a cognitive component, an emotional component, and an evaluative component (Bergami \& Bagozzi, 2000; Edwards, 2005; Ellemers, Kortekaas, \& Ouwerkerk, 1999; Jackson, 2002; Jackson \& Smith, 1999). The cognitive component represents a member's awareness of his/her membership status, or what some scholars refer to as self-categorization (Bergami \& Bagozzi, 2000). The emotional component is a member's 
sense of affect from being involved in the group. The evaluative component is a member's positive or negative assessment of the value of his/her membership in that particular group. Very little attention has been given to the causes and effects of the dimensions of group identification. Bergami and Bagozzi's (2000) study represents one of the few that modeled the antecedents and outcomes of various dimensions of identification. The final model included antecedents of organizational stereotypes and organizational prestige and outcomes of organizational citizenship behaviors.

In parallel fashion, we intend to show how the evaluative dimension of identification impacts certain perceptions that employees have regarding their work and ultimately, job performance using a sample of employees working for professional sport clubs in the United States. We note that because of the enormous attention given to professional sports in the United States (i.e., sponsorship dollars spent, TV viewership, attendance figures, number of TV channels devoted exclusively to sports) working for professional sport clubs in the United States represents a group that naturally allows for this type of exploration. To that end, we hereafter build and test a model that demonstrates the usefulness of considering employees' evaluations of a group's general worth, which Smith and Tyler (1997) call "pride."

\section{Theoretical Development}

Perhaps a simple illustration will help explain this concept. Imagine the situation where individuals are gathered in a public place like an airport or train station. Some of the individuals are engaged in a small talk, which usually involves information relative to family, hobbies, and work. One person is a marketing director for a nearby professional baseball team. Another person is a flower broker for a small florist in a local town. In general, which person would receive more attention because of his/her work? If asked, which person would say that they feel more valued and admired by outsiders (i.e., those not in one's work group (Ellemers et al., 1999) because of his/her work? We argue that, all things equal, more individuals in this public place would be intrigued with the marketing director's work compared to the work of the flower broker and consequently, we would expect that individual to feel more valued and admired by outsiders because of his/her work. For clarification, in this paper, we use the term "work" to refer to all elements of the employment context including one's profession, title, job, industry, department, position, and organization, similar to the way the social psychology writings previously mentioned considered only one's membership in a group, not one's particular role or position in that group.

Our rationale for considering one's membership (or non-membership) in a group is based in social identity theory, which maintains that people classify themselves into social categories, such as an organizational affiliation, an occupational affiliation, or religious membership, and rests on intergroup social comparisons which seek to confirm or establish in-group favoring and in-group/out-group distinctiveness (Tajfel \& Turner, 1986). These comparisons by members and potential members are usually motivated by the underlying needs for self-esteem and desires to be a part of some positively evaluated entity (Abrams \& Hogg, 1988). Hence, social identity is "that part of 
an individual's self-concept which derives from the knowledge of his/her membership in a social group (or groups) together with the value and emotional significance attached to that group membership" (Tajfel, 1981, p. 255). Using this theoretical framework, several writers have suggested that group identification contains at least three dimensions: (1) a cognitive component which is an awareness of one's membership in the organization, (2) an emotional component which is a sense of affective involvement with the organization, and (3) an evaluative component which is a positive or negative value connotation attached to group membership (Bergami \& Bagozzi, 2000; Edwards, 2005; Ellemers et al., 1999; Jackson, 2002; Jackson \& Smith, 1999). For instance, several researchers have investigated the cognitive dimension of group identification by exploring the degree to which group members perceive similarities between themselves and other group members, self categorize into particular groups, feel the group is a part of their inner self, and acknowledge membership in a particular group (Deaux, 1996; Ellemers et al., 1999; Jackson \& Smith, 1999; Karasawa, 1991).

Next, some researchers have investigated the affective dimension. Jackson and Smith (1999) state that group identities involve affect to the extent that cognitive and evaluative aspects of group members may be accompanied by emotions such as love or hatred, like or dislike. In this dimension of group identity, researchers like Deaux (1996) consider passionate feelings about group membership while Ellemers and colleagues (Ellemers et al., 1999) consider the degree to which members of the group like or dislike being a member, or would rather be in other groups. But only a few papers have considered the evaluative dimension of group identification, or pride (Jackson \& Smith, 1999; Smith \& Tyler, 1997; Tyler, Degoey, and Smith, 1996). We hope to extend this research by outlining a model detailing how pride impacts performance at work, and other organizationally relevant outcomes.

\section{A Model of Job Performance}

Our theoretical model is provided in Figure 1. The model forwards our expectation that pride is caused in part by feelings of prestige associated with one's work. In turn, pride produces organizational identification and job self-efficacy, each of which impacts job satisfaction, which ultimately leads to employee performance. In the sections that follow, we will provide support for each of the linkages in our proposed model.

\section{$\underline{\text { Prestige } \rightarrow \text { Pride } \rightarrow \text { Organizational Identification }}$}

The previous definition of social identity speculates that individuals are motivated to join particular groups in part out of a desire to boost their self esteem. If individuals then, desire to be positively evaluated by others, this desire necessitates an evaluation of the status of particular groups. Mael and Ashforth (1989) refer to this as the prestige of the group. Other scholars have examined elements of prestige and generally noted that individuals are particularly aware of status related issues involving their work, and that 


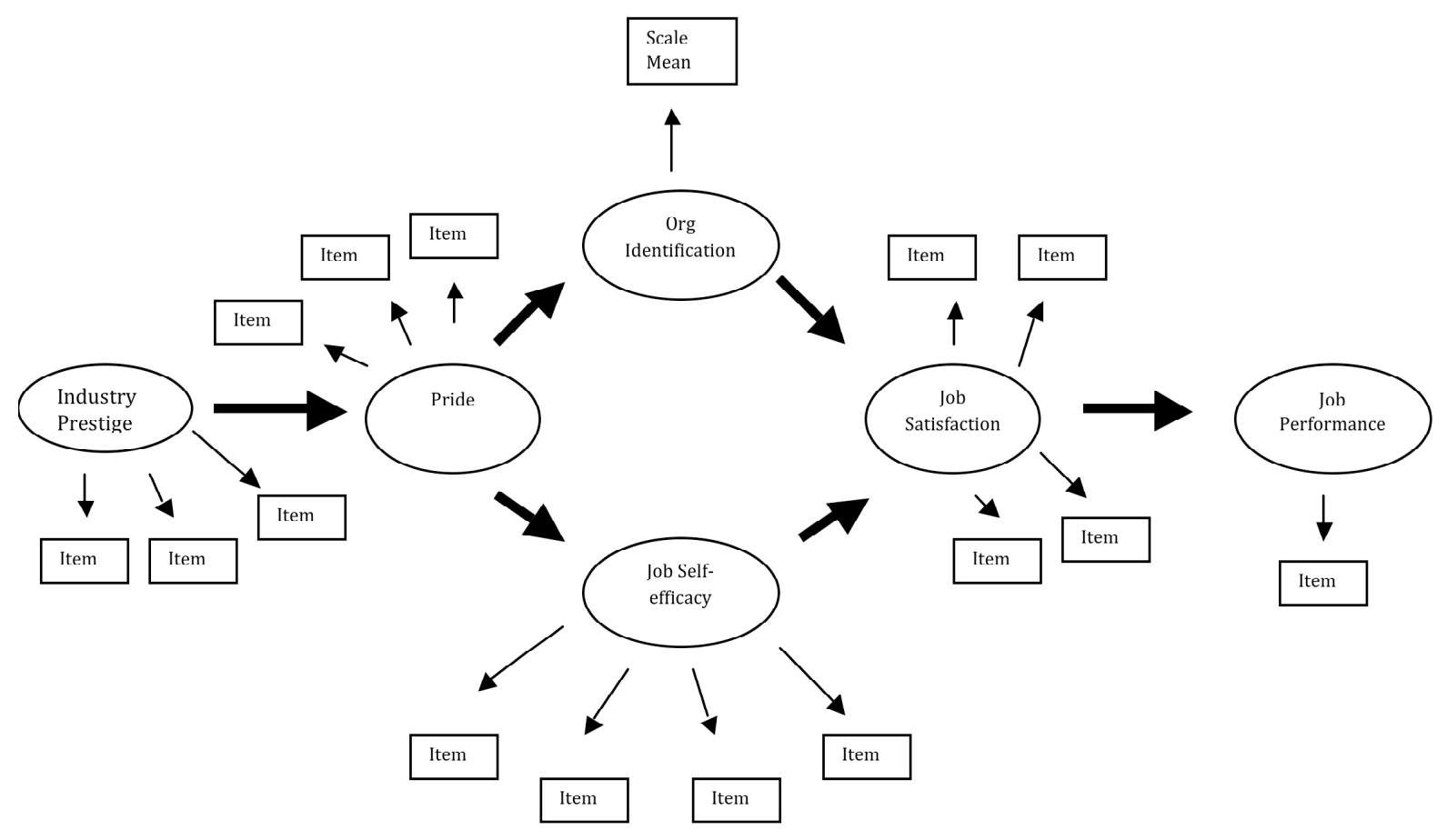

Figure 1. A Model of Performance in Professional Sport Clubs

most people desire to be part of a "winner" (e.g., Carmeli \& Freund, 2002; Dutton et al., 1994; Fuller et al., 2006; Mael \& Ashforth, 1992).

Researchers have suggested that membership in a high status social group is considered to be more attractive than membership in a low status group; therefore, members in high status groups are more likely to strive to maintain this membership by working towards status protection. These members of high status groups generally are more proud of their group membership, show stronger in-group identification and display more in-group favoritism than members of other low status groups. In support of this idea, extant research reveals that membership in high status social groups is considered more satisfactory than belonging to a group with low status (Ellemers, van Knippenberg, DeVries, \& Wilke, 1988; Ellemers, van Knippenberg, Doosje, \& Wilke, 1992; Ellemers, van Knippenberg, \& Wilke, 1990; Sachdev \& Bourhis, 1987). But, Ellemers and colleagues (Ellemers et al., 1999) argue that the relative status of the group is mostly related to the evaluative component of social identity which involves feeling proud, good, and respected as a member of a particular group. We expect the prestige of the group to first produce feelings of value, respect, and admiration in social settings (pride), then, to increase the degree to which a oneness with or belongingness to the organization is felt. Thus we expect:

Hypothesis 1: Prestige will be positively related to pride. 
Hypothesis 2: Pride will be positively related to organizational identification.

$$
\text { Pride } \rightarrow \text { Job self-efficacy }
$$

Job self-efficacy is often defined as a personal assessment of how capable one is of executing a required course of action (Bandura, 1986). Social cognitive theory (Bandura, 1997) provides the framework for our expectation that organizational identification would positively inflate job self-efficacy. If an employee feels a heightened sense of respect and value because of his/her job, it is reasonable that he/she would psychologically fabricate the belief that he/she should be the focus of the respect (or at least share the respect), rather than the work itself. Evidence for this can be seen in the work by Cialdini and colleagues (1976), who presented the term, "Basking in Reflected in Glory"(BIRG). This term explains the general tendency people have to associate with success, and to make others aware of particular accomplishments, even though vicarious in nature. The original study was a description of two experiments where college students showed a greater propensity to identify with their school's football team both by wearing apparel after a weekend in which the team was victorious and by using the pronoun "we" to describe the teams' past victory. The most telling aspect of the observed BIRGing phenomenon was that the students sought to proclaim the success of an athletic team, even when they had no personal role in it in order to be positively associated with something of value. In the case of employees who report feelings of respect and admiration by outsiders because of their work, we expect these feelings to inflate the sense in which they think they are competent in their work. That is, they would essentially "claim" the attention given to them because of their work for their own and report higher levels of job self-efficacy.

Additionally, previous research has shown that self-efficacy can develop from a number of different predictors. These include psychosocial factors, contextual variables, and social influences (Chin \& Kameoka, 2002; Slater, 1989). Further, Bandura (1997; Bandura, 2001) has suggested that self-efficacy beliefs can also be created through emotional states such as moods, arousal, happiness, and more. In essence, the emotional states that people experience provide cues about anticipated failure of success on the job. Applying this logic to our study, feelings of pride are likely to elicit positive feelings about the job in general and about completing the job (Bandura, 1997). These positive feelings have the effect of increasing confidence and in the process lead to higher levels of job self-efficacy.

Hypothesis 3: Pride will be positively related to job self-efficacy.

\section{Organizational Identification $\rightarrow$ Job Satisfaction}

Organizational identification refers to an individual's perceived belonging to his/her work organization, in terms by which organizational members define themselves (Ashforth \& Mael, 1989). We suggest that when organizational members identify more strongly with their work organizations (high organizational identification), they tend to view their jobs more positively. Job satisfaction, which is defined as "a pleasurable or positive 
emotional state resulting from the appraisal of one's job or job experiences" (Locke, 1976 , p. 1300), is a variable which captures the positive appraisal we predict is likely to result from organizational identification. A meta-analysis of the predictors of job satisfaction suggested antecedents fell into four main groupings of work outcomes, individual differences, role perceptions, and organizational variables (Brown \& Peterson, 1993). Although this study did not include organizational identification in the metaanalysis, the confidence interval of the correlation between value congruence and satisfaction was .32 and .82. In essence, those who identify with their organizations are likely to more favorably view aspects of their jobs, assignments, colleagues, and more, all of which contribute to increased levels of job satisfaction. Thus, we predict that:

Hypothesis 4: Organizational identification will positively predict job satisfaction.

\section{$\underline{\text { Job Self-efficacy } \rightarrow \text { Job satisfaction }}$}

As previously mentioned, job self-efficacy refers to an individual's belief about being able to successfully complete a job (Bandura, 1986). We anticipate that individuals who believe they are more competent in terms of completing their jobs (high job self-efficacy) will be higher in job satisfaction. Social cognitive theory again provides our rationale for this hypothesis. In particular, (Bandura, 1997) stated that "people's level of motivation, affective states, and actions are based more on what they believe than on what is objectively true" (p. 2). Accordingly, those who believe they are more efficacious at their jobs are likely to enjoy them more as they believe themselves to be good at them. For those who are lower in job self-efficacy, it is more difficult to enjoy work when they believe themselves to lack the ability to successfully complete the job. As a result, we suggest that job self-efficacy is positively related to job satisfaction, and this contention has been empirically supported in previous research (Judge \& Bono, 2001). Thus we predict that:

Hypothesis 5: Job self-efficacy will positively impact job satisfaction.

$$
\underline{\text { Job Satisfaction } \rightarrow \text { Job Performance }}
$$

There is a long standing debate over the primacy of job satisfaction over job performance. According to the Theory of Reasoned Action (e.g., Ajzen \& Fishbein, 1980; Hale, Householder, \& Greene, 2003; Sheppard, Hartwick, \& Warshaw, 1988), there is the belief that positive attitudes about a specific behavior (i.e., I like the tasks I have to perform) lead to behavioral intentions, which ultimately lead to improved job performance. The theory predicts that attitudes about a specific behavior serve as the proximal antecedents of behavioral intentions and the resulting job-related behavior (including job performance). Further, theory has shown that individuals perform better when they evaluate the job more positively (Judge et al., 2001). Thus, job satisfaction, an attitude that reflects an individual's overall evaluation of a job, is likely to be positively associated with job performance. In support of this idea, the meta-analytic results from Judge et al. (2001) show a correlation of .30 between job satisfaction and job performance. Thus we predict that: 
Hypothesis 6: Job satisfaction will positively impact employee job performance.

\section{Methods}

\section{Sample and Procedure}

The data were gathered as part of a larger consulting project related to salesperson performance in major league sports in the United States. In total, 15 professional sports teams participated in the research study. Managers for each team were selected through the personal contacts and networks of the authors. The teams included in the study were from Major League Soccer, National Basketball Association, and Major League Baseball. As a result of this project, managers from each team were provided information on various metrics that were internally useful in their business agendas; therefore, we were limited in the variety of questions we could ask.

Each manager supplied a list of contact information for the current salespeople employed by each team. Responsibilities of each salesperson varied from team to team, but included selling season tickets, group tickets, sponsorships, corporate suites, luxury boxes, and group ticket packages. We individually emailed each salesperson and asked each to participate in the study by clicking on a link to an online survey we developed. Concurrently, we emailed each manager an evaluation form that he/she completed for each salesperson under his/her supervision and the forms were returned electronically. The first wave of responses from sales reps totaled $42 \%$. We then sent an e mailed reminder to all reps and managers (to encourage the reps to complete the survey) and we received an additional $17 \%$ responses. In all, we collected 103 matched pairs, for a response rate of 59 percent. Demographic information was not collected because the managers considered this to be unnecessarily intrusive and irrelevant to their specific goals of the study. Also, the company officials were afraid that including demographic data would introduce an unwanted element of social desirability in the data and thus, prohibited us from collecting them.

\section{$\underline{\text { Measures }}$}

Unless otherwise noted, the response options for all of the following measures were 5point scales ranging from strongly disagree (1) to strongly agree (5). We reverse coded the items where necessary and averaged the items to form a construct score. In all cases, higher construct scores are indicative of higher levels of the variable.

\section{Prestige}

Because the individual organizations used in this survey were professional sport teams, we did not want to use the organization as the target of the prestige for several reasons: (1) the data were comprised of account representatives, who by nature are customer contact individuals and often hear a lot of comments directed at the organization from fans in the course of their interactions, and (2) these comments could bias the 
organizational image of the employee depending upon the win/loss record of the team at the time of the study. Our goal was not to capture the specific prestige of the company, but the prestige of working in professional sports, thus, we generalized the prestige of the job to the industry. We used the perceived organizational prestige measure found in Mael and Ashforth (1992) as a guide to help us construct the 3-item measure of industry prestige. The items in the current study demonstrated acceptable reliability $(\alpha=.75)$. The items were, "The professional sports industry is highly attractive to outsiders as a place to work," "In general, people think jobs in professional sports are fascinating," and "Many people I meet would die to work in professional sports."

\section{Organizational identification}

We used the 6-item scale presented in Mael and Ashforth (1992) to measure the degree to which employees identify with the organization. In the current study, the coefficient alpha reliability $(\alpha=.78)$ estimate was acceptable. A sample item is "When someone criticizes my organization, it feels like a personal insult."

\section{Pride}

We developed three items to measure pride and patterned them after the items used by Smith and Tyler (1997) and Jackson (2002). The items were, "I feel especially respected in social settings when I discuss my job in sports," "My job gives me a feeling of importance when talking to others outside work," and "In social settings, I feel valued and admired because of my job." The alpha reliability $(\alpha=.76)$ for this measure was acceptable.

\section{$\underline{\text { Job satisfaction }}$}

We used the job satisfaction scale of Judge, Bono, and Locke (2000) and Judge, Locke, Durham, and Kluger (1998) which consists of five items. The items showed acceptable reliability $(\alpha=.76)$. A sample item is "Most days I am enthusiastic about my work."

\section{$\underline{\text { Job self-efficacy }}$}

We measured job self-efficacy with the four item scale from Krishnan and colleagues (2002). The scale demonstrated acceptability $(\alpha=.81)$. A sample item is "I know the right thing to do in selling situations."

\section{Overall job performance}

Because the data for this study were part of a larger consulting project on the performance of account representatives, we wanted to ensure that our measure of performance was similar to those that the managers actually use when evaluating their staff. We conducted several conference calls with sales participating managers around the various leagues to gather information on the components of performance they evaluate in an employee. Next, we identified eight components that were most 
important to managers when evaluating the performance of account representatives ranging from the ability to generate referrals, to cooperating with others on the staff, to meeting revenue goals. We listed these eight items on the form that was sent to managers and then included as the last question "Overall, how would you rate the performance of this salesperson?" All of the performance items were set on a $1-10$ Likert-type scale from "much below expectations" to "consistently exceeds expectations." We extended the scale range for the performance measure out of a concern expressed by managers who wanted to be able to show greater levels of demarcation between staff members. After discussing the scale with management, we elected to use the single item measure as an overall indicator of performance in the current study. The rationale behind this was that if we aggregated the eight components to form an average measure, we would in the process be placing equal weights on each item, when in reality, each manager incorporated differential weights (either on pen-andpaper or more likely in thought) when making the overall assessment of performance. Thus, we considered the overall assessment to be more realistically accurate because it captured the individual preferences of each manger. Finally, the overall item was the actual item used for performance appraisals in many of the teams, thus, we wanted to maintain consistency. As an added measure of precaution, we checked the correlation between the one item overall measure of job performance and the aggregated measure of job performance derived from averaging the scores of the 8 performance items and found a correlation of .83 between the two constructs.

\section{Results}

An inspection of the data for violations of assumptions (linearity of data, independent observations, and distributional characteristics) and normality (skewness, kurtosis, etc.) yielded no significant concerns. Moreover, according to Hair and colleagues (Hair et al., 1998) the minimum sample size required to ensure proper model fit when utilizing the maximum likelihood estimation procedure is between 100-150. The means, standard

\section{Table 1}

\begin{tabular}{|c|c|c|c|c|c|c|c|c|c|}
\hline \multicolumn{10}{|c|}{ Means, Standard Deviations, and Bivariate Correlations } \\
\hline & & & & & & & & & \\
\hline & & Mean & SD & 1 & 2 & 3 & 4 & 5 & 6 \\
\hline \multicolumn{2}{|c|}{1 Prestige } & 4.22 & 59 & .75 & & & & & \\
\hline \multicolumn{2}{|c|}{2 Pride } & 3.80 & .65 & $.39 *$ & .76 & & & & \\
\hline \multicolumn{2}{|c|}{3 Org ID } & 4.06 & .57 & $.31 \%$ & $.43^{*}$ & .78 & & & \\
\hline \multicolumn{2}{|c|}{4 Job Self Efficacy } & 4.29 & .47 & $.25^{*}$ & $.26^{*}$ & $.22^{*}$ & .81 & & \\
\hline \multicolumn{2}{|c|}{5 Job Satisfaction } & 3.96 & .61 & .10 & $.34^{* t}$ & $.44 *$ & $.33^{*}$ & .76 & \\
\hline \multicolumn{2}{|c|}{6 Performance } & 6.59 & 1.79 & .07 & .16 & $.28^{*+1}$ & .14 & $.31^{\#+}$ & -- \\
\hline & & & & & & & & & \\
\hline \multirow[t]{3}{*}{ Note } & \multicolumn{7}{|c|}{ alpha reliabilities are presented on the diagonal, correlations on the off diagonal } & & \\
\hline & \multicolumn{4}{|c|}{ * correlation is significant at the .01 level } & & & & & \\
\hline & \multicolumn{4}{|c|}{ * correlation is significant at the .05 level } & & & & & \\
\hline
\end{tabular}


deviations, and intercorrelations for all constructs included in the study are presented in Table 1.

We tested the hypotheses using path analyses conducted using LISREL 8.54 (Jöreskog \& Sörbom, 2001). A path analysis was the appropriate analytical tool as we measured a process model and were only interested in the paths, not necessarily the overall model. To run the models, we utilized covariance matrices as inputs with the maximum likelihood (ML) method. Figure 1 details the hypothesized predictions as well as the full measurement model. For all SEM reports, we used likelihood ratio chi square statistics in addition to other supplemental fit indexes. According to Hu and Bentler (1999), the adequacy of SEM models should be judged by the following recommended cutoff criterion for the ML based indexes: Root Mean Square Error of Approximation (RMSEA) $<.06$, Standardized Root Mean Squared Residual $(S R M R)<.08$, and Comparative Fit Index $(\mathrm{CFI})>.95$. Before conducting the test of the full structural model, we tested the fit of the measurement model to the data and found acceptable fit $\left(x^{2}=104\right.$ (df 71), $p<$ .05 ; RMSEA $=.06$; SRMR $=.06$; CFI $=.96$ ). We note that this test of the fit of the measurement model to the data is essentially the same process as a confirmatory factor analysis in LISREL software. For comparison, we used the same covariance matrices as inputs, but set all the indicators to one common factor and found the fit to be unacceptable (RMSEA $=.2$; SRMR $=.14 ; \mathrm{CFI}=.68)$. Thus, we have confidence that our measurement model is sound. Next, we estimated the full structural model, which had the same indicator structure as the measurement model, but included direct paths between prestige and pride $(\mathrm{H} 1)$, pride and organizational identification $(\mathrm{H} 2)$, organizational identification and job self-efficacy $(\mathrm{H} 3)$, organizational identification and job satisfaction ( $\mathrm{H} 4)$, job self-efficacy and job satisfaction ( $\mathrm{H} 5)$, and job satisfaction and job performance $(\mathrm{H} 6)$. The goodness-of-fit statistic for this model was not significant, indicating a good fit of the model to the data $\left(x^{2}=55.61\right.$, df 100) and supplemental fit indexes were also indicative of a good model specification (RMSEA $=.0$; SRMR $=.04$; $\mathrm{CFI}=.99)$.

Results from this model are shown in Table 2. Hypothesis 1 received support, as prestige positively impacted pride $(B=.56, z=2.82)$. Hypothesis 2 received support, as pride positively impacted organizational identification $(B=.41, z=2.68)$. Hypothesis 3 , stating the expectation that organizational identification would predict job self-efficacy, received support $(B=.41 ; z=2.07)$. Hypothesis 4 and 5 forwarded the expectations that organizational identification and job self-efficacy would both predict job satisfaction. These two hypotheses were both supported $[(\mathrm{H} 4: \mathrm{B}=.47 ; \mathrm{z}=3.46),(\mathrm{H} 5: \mathrm{B}=.37 ; \mathrm{z}=$ 2.27)]. Finally, Hypothesis 6 stated that job satisfaction would positively predict job performance. Our results $(B=.88 ; z=4.39)$ provided support for this Hypothesis. Overall, the model explained $33 \%$ variance in pride, $17 \%$ variance in organization identification, $17 \%$ variance in job self-efficacy, $42 \%$ variance in job satisfaction, and $77 \%$ variance in job performance. 
Table 2

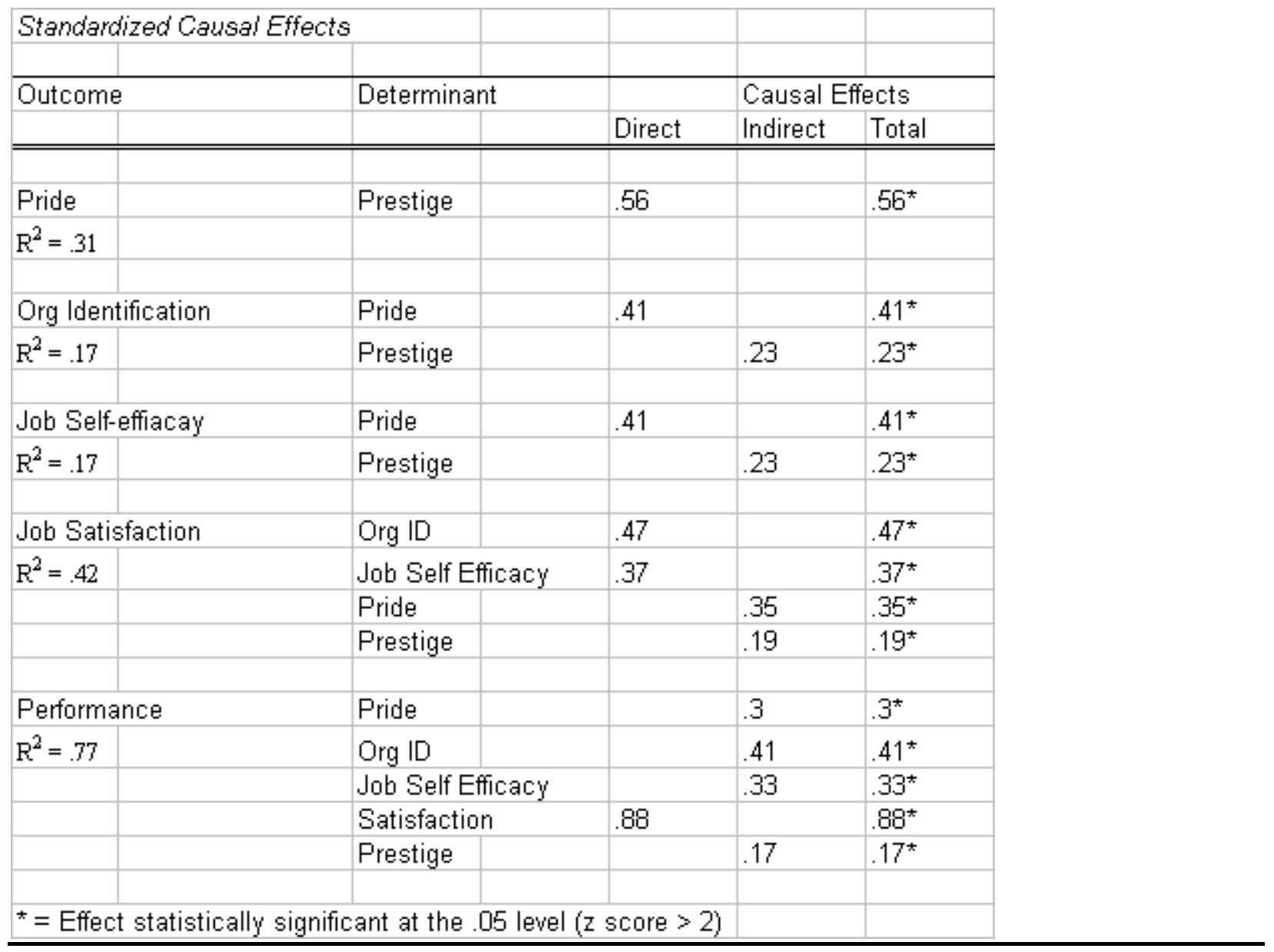

\section{Discussion}

In this study, we set out to explore the impact that work can have on the degree to which individuals feel especially respected, valued, and admired when talking to outsiders. Similar to other scholars, we consider this construct to be representative of the evaluative dimension of organizational (or group) identification, or what others have labeled "pride" (Ellemers et al., 1999; Jackson, 2002, Smith \& Tyler, 1997). We developed a model to explain the role of pride in organizations that suggested the prestige of work (in this study, work in the professional sports industry) ultimately led to increased job performance in the form of sales performance. The support of the model in the current setting suggests that employees who work in prestigious settings often feel especially admired, respected, and valued by outsiders and it is this feeling that leads to higher levels of organizational identification and other work related outcomes. In light of our findings, we suggest that elements of prestige lead to employees feeling especially respected by outsiders because of their work, which then produces organizational identification and job self-efficacy. In the spirit of the earlier example, the marketing director for the nearby professional baseball team would surely report higher 
levels of respect and admiration in public settings as a function of the uniqueness of the job and the prestige surrounding it. In fact, our sample involved employees who worked for professional sports teams in a sales capacity. Given the interest that is devoted to professional sports in the United States, we would expect the employees from these teams to feel especially respected and admired in public settings because of the scarcity, status, and uniqueness of their jobs.

Overall, our model explained $77 \%$ of the variance in sales performance as rated by supervisors. It appears that many employees in the sample are impacted by elements of prestige to the point that they perform better on their jobs. Additionally, our process model showed that the prestige begins the model, but then there are a number of intermediary mechanisms (e.g., pride, job satisfaction) that ultimately translate prestige into job performance. These findings are important as they provide managers with additional information for increasing employees' job performance. In particular, managers can do everything in their power to increase the perceptions of prestige and pride that individuals feel.

Our model suggested that $33 \%$ of the variance in pride was accounted for by the prestige of the work. This finding corresponds to conclusions drawn by many researchers that groups that are more prestigious are more attractive than those without high levels of prestige. Indeed, at the heart of social identity theory is the assumption that people are attracted to groups, in part, out of a desire to enhance self esteem, or to be affiliated with a group that is positively evaluated (Mael \& Ashforth, 1992).

We also discovered that $17 \%$ of the variance in organizational identification was explained by pride, which suggests the constructs are not the same. This result appears to promote the belief that the prestige of working in professional sports first impacts employees in an evaluative sense, then impacts individuals to the extent to which they feel a heightened degree of belonging, or identification to the group. Perhaps this is explained in part by Jackson (2002) who discovered that the evaluative dimension of identification (labeled 'attraction to the ingroup' in the paper) was significantly related to intergroup bias and positive attitudes towards the ingroup. This finding suggests that as group members were more attracted to the group, their intergroup bias increased as well as the extent to which they held positive attitudes towards their group membership. In a similar fashion, our data suggests employees who experienced the social gratification of feeling valued, admired, and especially respected because of their work tended to feel a stronger sense of belonging to the work (or group or organization). Additionally, the process model that we examined and found support for provides both a predictor and direct and indirect outcomes from pride.

\section{Limitations}

Although this study makes a contribution to the extant research and has a number of strengths, there are limitations that must be acknowledged to properly interpret the study's results. First was our use of the single-item measure of overall job performance. Our reasoning for using this measure it is utilized for our respondents as their overall 
performance rating for compensation and promotion purposes. However, we realize that although we provided the rationale for using only the single item and researchers have argued for and shown the appropriateness of employing single item measures (Wanous et al., 1997), this may still be viewed as a limitation. Second, this current study was the first to examine the pride measure. Our findings showed the scale had sound internal consistency and was distinct from somewhat similar variables, but we recommend further studies that more explicitly examine the measure. In particular, there is a need to examine the nomological network related to pride as well as variables that may be similar, so it can better be shown how pride is making a unique contribution to the extant literature.

Third, all of our data were collected at the same time using the same method, thus resulting in concerns related to common method variance (CMV). This was the goal of our study as we were interested in employees' perceptions and views about constructs, such as prestige and pride, and it would not have aligned with our theoretical arguments and predictions if we would have examined these variables from other perspectives. Additionally, we used supervisor ratings of job performance to help minimize these concerns. Nonetheless, they must still be acknowledged. Finally, our sample characteristics should be mentioned as limitations. For one, our sample was not as large as we would have liked, which generates concerns related to the amount of error in our findings. However, on the flipside we note that in light of our sample size, the relationships between the constructs were rather robust. Another limitation of our sample is that it did not afford us the opportunity to analyze non-respondent bias, due in part to the difficulty in obtaining data from professional sports teams and the desire of the managers to ensure anonymity. We do think that non-respondent bias impacted the internal validity to a great degree in this current study because the response rate was so high $(59 \%)$.

\section{$\underline{\text { Future Research }}$}

The construct of pride attempts to capture to appreciated feelings of respect and admiration employees sometimes feel when talking to outsiders about their work. We have noted the distinction between pride and the traditional view of organizational identification, but have also suggested that pride could be way to operationalize the evaluative component of organizational identification. The model that we tested in this current study suggests pride to be an important predictor of both organizational identification and job self-efficacy, which ultimately increased job performance in the sample of salespeople in professional sport clubs. However, future research should indeed pursue instrument validation through standard and acceptable procedures. Specifically, we hope future research efforts will examine this variable in other contexts in an attempt to extend the generalizability and establish boundary conditions related to pride.

Future research should also investigate the role of attitudinal importance as a moderator of the link between pride and attitudinal/behavioral outcomes. It is likely that the degree to which pride impacts the aforementioned employee outcomes is contingent upon the 
strength of the employee's attitude regarding the importance of pride. Previous work (Krosnick et al., 1993) has conceptualized attitude strength as a multidimensional construct, containing attitude importance as one of the dimensions. Eagly and Chaiken (1998) suggest that attitude importance is best viewed as an "experiential strength variable," or a metacognition held in relation to one's attitude (p. 290). Similarly, Boninger, Krosnick, and Berent (1995) define attitude importance as the "individual's subjective sense of the concern, caring, and significance he or she attaches to an attitude" (p. 62). As such, we invite future researchers to examine the idea that the degree to which pride directly impacts important outcomes is contingent upon the importance of the attitude for each individual.

Finally, future work should examine non-direct relationships between these variables. For example, it is possible that the impact of pride upon organizationally relevant job attitudes would fade over time (e.g., an employee is extra proud to work at a certain job, but over time, this becomes the "normal" job and the pride becomes somewhat less"), and thus, perhaps job tenure would moderate these relationships. Other potential moderators include family concerns, self-esteem, and the impact of workplace social relationships. Additionally, future researchers should attempt to determine if pride is curvilinearly related to important outcomes. The idea behind this suggestion is that for jobs with minimal amounts of prestige, the pride may have a positive, but minimal effect. However, when prestige is greater (e.g., an employee of the Red Cross or the Indianapolis Colts), the effect of pride may be a great deal stronger, thus resulting in a non-linear relationship. We invite future researchers to examine this notion.

\section{Practical Implications}

From our results, there are several practical implications. The biggest of these is the importance of pride. We found that pride was a significant predictor of both organizational identification and job self-efficacy, both of which have been shown to be important variables in the workplace (Bandura, 1986, 1997; Wegge et al., 2006). Thus, managers could benefit from any programs, exercises, reports, or the like that help to increase pride. Some potential areas might be telling employees about the accomplishments of the organization, and working as hard as possible to have high standings in rankings of corporate reputations or other such publications. Additionally, managers should make every effort to make employees feel that their jobs and their organizations are prestigious, as this was found to lead to pride. Indeed, this task is easier in some organizations where societal veneration for the industry or company is exceedingly high (like professional sport clubs, military units, The Federal Reserve, most admired companies, etc).

Similarly, when looking at our model as a causal process predicting job satisfaction and job performance, managers should be aware that there are a large number of predictors of these variables. In particular, we know about and often focus on the importance of such variables as compensation, leadership, teamwork, personality, and other known antecedents. However, this study points to other predictors and shows that managers can not forget about the prestige and resulting pride that employees feel. Further, a 
great deal of these feelings comes from external views, those stemming from outside the "organizational walls." Thus, although we are in no way suggesting managers should not devote time and energy to internal issues, they should not do this at the expense of promoting and "selling" the organization externally.

\section{$\underline{\text { Conclusion }}$}

The preceding discussion has been presented as an initial attempt to explain how one's work can generate feelings of admiration, value, and respect when talking to outsiders. Pride is a construct intuitively suggesting that some employees receive certain psychological benefits from their work related "memberships." These benefits, in turn, impact organizationally relevant attitudes and behaviors. In this study, we discovered that work performance was generated in part from these feelings of value, admiration, and respect; however, there are many other possibilities for future exploration of this concept. As this current study has provided an initial step in examining a potentially new variable, we hope future researchers will extend our research and continue to expand the nomological network related to pride.

\section{References}

Abrams, D., \& de Moura, G. R. (2001). Organizational identification: Psychological anchorace and turnover. In M. A. Hogg \& D. J. Terry (Eds.), Social identity processes in organizational contexts (pp. 131-147). Philadelphia, PA: Psychology Press.

Abrams, D., \& Hogg, M. A. (1988). Comments on the motivational status of self-esteem in social identity and intergroup discrimination. European Journal of Social Psychology, 18(4), 317-334.

Ajzen, I., \& Fishbein, M. (1980). Understanding attitudes and predicting social behavior. Englewood Cliffs: NJ: Prentice Hall.

Ashforth, B. E., \& Mael, F. (1989). Social identity theory and the organization. Academy of Management Review, 14(1), 20-39.

Bandura, A. (1986). Social foundations of thought and action: A social-cognitive theory. Upper Saddle River, NJ: Prentice-Hall.

Bandura, A. (1997). Self-efficacy: The exercise of control. New York: W. H. Freeman and Company.

Bandura, A. (2001). Social cognitive theory: An agentive perspective. Annual Review of Psychology, 52, 1-26. 
Bergami, M., \& Bagozzi, R. P. (2000). Self-categorization, affective commitment and group self-esteem as distinct aspects of social identity in the organization. British Journal of Social Psychology, 39(4), 555-577.

Boninger, D. S., Krosnick, J. A., \& Berent, M. K. (1995). Origins of attitude importance: Self-interest, social identification, and value relevance. Journal of Personality and Social Psychology, 68(1), 61-80.

Brown, S. P., \& Peterson, R. A. (1993). Antecedents and consequences of salesperson job satisfaction: Meta-analysis and assessment of causal effects. Journal of Marketing Research, 30 (February), 63-77.

Carlson, D. S., \& Perrewé, P. L. (1999). The role of social support in the stressor-strain relationship: An examination of work-family conflict. Journal of Management, 25(4), 513-540.

Carmeli, A., \& Freund, A. (2002). The relationship between work and workplace attitudes and perceived external prestige. Corporate Reputation Review, 5(1), 51-68.

Chin, D., \& Kameoka, V. (2002). Psychological and contextual predictors of educational and occupational self-efficacy among hispanic inner-city adolescents. Hispanic Journal of Behavioral Sciences, 24(2), 448-464.

Cialdini, R. B., Borden, R. J., Thorne, A., Walker, M. R., Freeman, S., \& Sloan, L. R. (1976). Basking in reflected glory: Three (football) field studies. Journal of Personality and Social Psychology, 34(3), 366-375.

Deaux, K. (1996). Social identification. In E. T. Higgins \& A. W. Kruglanski (Eds.), Social psychology: Handbook of basic principles. New York: Guilford.

Dutton, J. E., Dukerich, J. M., \& Harquail, C. V. (1994). Organizational images and member identification. Administrative Science Quarterly, 39, 239-263.

Eagly, A. H., \& Chaiken, S. (1998). Attitude structure and function. In D. T. Gilbert, S. T. Fiske \& G. Lindzey (Eds.), The handbook of social psychology (4 ed., Vol. 1, pp. 269-322). New York: McGraw-Hill.

Edwards, M. R. (2005). Organizational identification: A conceptual and operational review. International Journal of Management Reviews, 7(4), 207-230.

Ellemers, N., Kortekaas, P., \& Ouwerkerk, J. W. (1999). Self-categorisation, commitment to the group and group self-esteem as related but distinct aspects of social identity. European Journal of Social Psychology, 29(2-3), 371-389.

Ellemers, N., van Knippenberg, A., De Vries, N., \& Wilke, H. (1988). Social identification and permeability of group boundaries. European Journal of Social Psychology, 18(6), 497-513. 
Ellemers, N., van Knippenberg, A., Doosje, B., \& Wilke, H. (1992). Status protection in high status minority groups. European Journal of Social Psychology, 22(2), 123140.

Ellemers, N., van Knippenberg, A., \& Wilke, H. (1990). The influence of permeability of group boundaries and stability of group status on strategies of individual mobility and social change. British Journal of Social Psychology, 29(3), 233-246.

Fuller, J. B., Hester, K., Barnett, T., Frey, L., Relyea, C., \& Beu, D. (2006). Perceived external prestige and internal respect: New insights into the organizational identification process. Human Relations, 59(6), 815-846.

Gardner, D. G., \& Pierce, J. L. (1998). Self-esteem and self-efficacy within the organizational context: An empirical examination. Group \& Organization Management, 23(1), 48-70.

Gemmill, G. R., \& Heisler, W. J. (1972). Machiavellianism as a factor in managerial job strain, job satisfaction, and upward mobility. Academy of Management Journal, 15(1), 51-62.

Hair, J. F., Jr., Anderson, R. E., Tatham, R. L., \& Black, W. C. (1998). Multivariate data analysis. Upper Saddle River, NJ: Prentice Hall.

Hale, J. L., Householder, B.J., \& Greene, K.L. (2003). The theory of reasoned action. In J.P. Dillard \& M. Pfau (Eds.), The persuasion handbook: Developments in theory and practice (pp. 259 - 286). Thousand Oaks, CA: Sage.

Hu, L., \& Bentler, P. M. (1999). Cutoff criteria for fit indexes in covariance structure analysis: Conventional criteria versus new alternatives. Structural Equation Modeling, 6(1), 1-55.

Iverson, R. D., \& Maguire, C. (2000). The relationship between job and life satisfaction: Evidence from a remote mining community. Human Relations, 53(6), 807-839.

Jackson, J. W. (2002). Intergroup attitudes as a function of different dimensions of group identification and perceived intergroup conflict. Self and Identity, 1(1), 1133.

Jackson, J. W., \& Smith, E. R. (1999). Conceptualizing social identity: A new framework and evidence for the impact of different dimensions. Personality and Social Psychology Bulletin, 25(1), 120-135.

Jöreskog, K. G., \& Sörbom, D. (2001). Lisrel 8: User's reference guide. Lincolnwood, IL: Scientific Software International.

Judge, T. A., \& Bono, J. E. (2001). Relationship of core self-evaluations traits--- selfesteem, generalized self-efficacy, locus of control, and emotional stability---with 
job satisfaction and job performance: A meta-analysis. Journal of Applied Psychology, 86(1), 80-92.

Judge, T. A., Bono, J. E., \& Locke, E. A. (2000). Personality and job satisfaction: The mediating role of job characteristics. Journal of Applied Psychology, 85(2), 237249 .

Judge, T. A., Locke, E. A., Durham, C. C., \& Kluger, A. N. (1998). Dispositional effects on job and life satisfaction: The role of core evaluations. Journal of Applied Psychology, 83(1), 17-34.

Judge, T. A., Thorenson, C. J., Bono, J. E., \& Patton, G. K. (2001). The job satisfaction-job performance relationship: A qualitative and quantitative review. Psychological Bulletin, 127(3), 376-407.

Karasawa, M. (1991). Toward an assessment of social identity: The structure of group identification and its effects on in-group evaluations. British Journal of Social Psychology, 30(4), 293-307.

Krishnan, B. C., Netemeyer, R. G., \& Boles, J. S. (2002). Self-efficacy, competitiveness, and effort as antecedents of salesperson performance. Journal of Personal Selling \& Sales Management, 22(4), 285-295.

Krosnick, J. A., Boninger, D. S., Chuang, Y. C., Berent, M. K., \& Carnot, C., G. (1993). Attitude strength: One construct or many related constructs? Journal of Personality and Social Psychology, 65(6), 1132-1151.

Locke, E. A. (1976). The nature and causes of job satisfaction. In M. D. Dunnette (Ed.), Handbook of industrial and organizational psychology (pp. 1297-1349). Chicago: Rand McNally.

Mael, F., \& Ashforth, B. E. (1992). Alumni and their alma mater: A partial test of the reformulated model of organizational identification. Journal of Organizational Behavior, 13, 103-123.

Mael, F. A., \& Tetrick, L. E. (1992). Identifying organizational identification. Educational and Psychological Measurement, 52(4), 813-824.

Paully, I. M., Alliger, G. M., \& Stone-Romero, E. F. (1994). Construct validation of two instruments designed to measure job involvement and work centrality. Journal of Applied Psychology, 79(2), 224-228.

Sachdev, I., \& Bourhis, R. Y. (1987). Status differentials and intergroup behaviour. European Journal of Social Psychology, 17(3), 277-293.

Schaubroeck, J., \& Merritt, D. E. (1997). Divergent effects of job control on coping with work stressors: The key role of self-efficacy. Academy of Management Journal, 40(3), 738-754. 
Sheppard, B.H., Hartwick, J., \& Warshaw, P.R. (1988). The theory of reasoned action: A meta-analysis of past research with recommendations for modifications and future research. Journal of Consumer Research, 15, 325-343.

Slater, M. D. (1989). Social influences and cognitive control as predictors of self-efficacy and eating behavior. Cognitive Therapy and Research, 13, 231-245.

Smith, H. J., \& Tyler, T. R. (1997). Choosing the right pond: The impact of group membership on self-esteem and group-oriented behavior. Journal of Experimental Social Psychology, 33(2), 146-170.

Tajfel, H. (1981). Human groups and social categories: Studies in social psychology. Cambridge, UK: Cambridge University Press.

Tajfel, H., \& Turner, J. C. (1986). The social identity theory of inter-group behavior. In S. Worchel \& L. W. Austin (Eds.), Psychology of intergroup relations. Chicago: Nelson-Hall.

Tyler, T. R., \& Lind, E. A. (1992). A relational model of authority in groups. In M. Zanna (Ed.), Advances in experimental social psychology (Vol. 25, pp. 115-191).

Wanous, J. P., Reichers, A. E., \& Hudy, M. J. (1997). Overall job satisfaction: How good are single-item measures? Journal of Applied Psychology, 82(2), 247-252.

Wegge, J., Van Dick, R., Fisher, G. K., Wecking, C., \& Moltzen, K. (2006). Work motivation, organizational identification, and well-being in call centre work. Work \& Stress, 20(1), 60-83. 